\title{
Zastosowanie symulatora ChemCAD do modelowania osuszania n-butanolu poprzez destylację heteroazeotropową
}

\begin{abstract}
Przedstawiono symulacje osuszania n-butanolu poprzez destylację heteroazeotropową przy użyciu: toluenu, p-ksylenu, cykloheksanu i n-heksanu oraz bez użycia składnika trzeciego. Zastosowano do tego celu symulator ChemCAD, wybierając jako opcję termodynamiczną do obliczania równowag fazowych równanie NRTL. Do rozpatrywanych mieszanin współczynniki tego równania dopasowano osobno, wykorzystując dane równowagi ciecz-ciecz-para (VLLE) oraz równocześnie dane równowagi ciecz-para (VLE). Obliczono, z jaką dokładnością parametry modelu (zwanego dalej NRTL-VLL) opisują VLLE, VLE oraz równowagi ciecz-ciecz (LLE) układu powstałego w rozdzielaczu. $\mathrm{W}$ przypadku toluenu i p-ksylenu wykonano również symulacje z użyciem oryginalnych współczynników równania NRTL z bazy danych ChemCAD. Okazały się one znacznie mniej dokładne od symulacji przy wykorzystaniu parametrów modelu NRTL-VLL. Dla każdej symulacji obliczono wymagania energetyczne związane z odbiorem ciepła w skraplaczach kolumn i chłodnicach oraz z dostarczeniem ciepła w wyparkach kolumn i podgrzewaczach.
\end{abstract}

Słowa kluczowe: osuszanie n-butanolu, destylacja heteroazeotropowa.

\section{Application of the ChemCAD simulator for modeling of $n$-butanol dehydration via heterogeneous azeotropic distillation}

\begin{abstract}
The paper presents the simulations of n-butanol dehydration via heterogeneous azeotropic distillation using: toluene, p-xylene, cyclohexane and n-hexane as well as without the use of entrainer. Calculations were performed with the ChemCAD simulator using the NRTL equation for phase equilibria computation. The NRTL equation coefficients of the considered ternary mixtures were fitted to the vapour-liquid-liquid equilibrium data (VLLE) and simultaneously to the vapour-liquid equilibrium data (VLE). The accuracy of description of the VLLE, the VLE by the model hereinafter referred to as NRTL-VLL has been presented. The compatibility of the concentrations of the liquid phases formed in the decanter with the experimental liquid-liquid equilibrium data (LLE) was shown on the graphs. The simulations using the original NRTL coefficients from the ChemCAD database were performed for toluene and p-xylene. The results of these simulations were far less accurate than those using the NRTL-VLL model parameters. For each simulation the energy requirements were calculated. They take into account separately, the heat duties in the column condensers and the cooler and the heat duties in the column reboilers and heaters.
\end{abstract}

Key words: n-butanol dehydration, heterogeneous azeotropic distillation.

\section{Wstęp}

W ostatnich latach coraz bardziej wzrasta zainteresowanie zastosowaniem alkoholi (etanol, $\mathrm{n}$ - i izopropanol oraz n-butanol) jako dodatku do paliw silnikowych oraz jako samodzielnego paliwa. Jeżeli alkohol wytwarza się poprzez biologiczną fermentację, otrzymuje się jego wodny roztwór o niskim stężeniu. Wszystkie z powyższych alkoholi two- rzą z wodą azeotrop dodatni o minimum temperatury wrzenia i z tej przyczyny nie można ich uzyskać w formie bezwodnej drogą zwykłej destylacji. Jedną z technik pozwalających uzyskać alkohol zawierający minimalną ilość wody jest destylacja heteroazeotropowa. Do rozdzielanej mieszaniny dodaje się składnik trzeci, który tworzy z jej substan- 
cjami heteroazeotrop trójskładnikowy. Ten ostatni odchodzi górą kolumny azeotropowej, a dołem odprowadza się alkohol o bardzo dużej czystości. Heteroazeotrop wykrapla się i rozdziela na fazę organiczną, zawracaną jako orosienie do kolumny azeotropowej, i na fazę wodną, kierowaną do drugiej kolumny destylacyjnej. Ta ostatnia dołem odprowadza czystą wodę, a górą - mieszaninę zbliżoną składem i temperaturą do dwuskładnikowego azeotropu woda-alkohol, kierowaną do kolumny azeotropowej.

Destylacja azeotropowa może być realizowana z użyciem różnych substancji w charakterze składnika trzeciego. Powstałe schematy mogą być analizowane za pomocą symulatorów procesów technologicznych, jak np. ChemCAD [4]. Należy jednak pamiętać, że dokładność symulacji jest bardzo mocno uzależniona od precyzji, z jaką wybrany przez użytkownika model termodynamiczny opisuje w rozpatrywanym przypadku zarówno równowagę VLE, jak i LLE. Ponieważ osuszanie alkoholi prowadzi się pod ciśnieniami bliskimi atmosferycznemu, do opisu termodynamicznego używa się równań obliczających współczynniki aktywności ułamkowej $\gamma_{i}$. Jednym z najlepszych modeli jest tu równanie NRTL, w którym jednak współczynniki dopasowuje się do równowagowych danych eksperymentalnych. Jeśli użyje się danych typu LLE, to równanie dobrze opisuje ten typ równowagi, ale niedokładnie opisuje VLE i na odwrót. Baza danych symulatora ChemCAD zawiera takie właśnie współczynniki. W związku z tym parametry te powinny być dopasowane z zewnątrz do danych trójfazowych VLLE. Dodatkowo, aby równanie opisywało również dobrze region odległy od VLLE, parametry równania NRTL powinny być dopasowane równocześnie do danych VLE, które mogą dotyczyć zarówno danych trójskładnikowych, jak i dwuskładnikowych podsystemów tworzących rozpatrywany układ. Szczegółowy opis algorytmu obliczania tych współczynników, jak i ich wartości dopasowane dla 27 układów trójskładnikowych przedstawiono w pracy [20]. Publikowano już prace dotyczące symulacji odwadniania etanolu [2, 5, 12, 17, 21], n-propanolu [16] i izopropanolu [1, 3, 19], jednak z wyjątkiem artykułu [21] prace te nie pokazują, z jaką dokładnością wyniki symulacji opisują dane LLE.

Celem niniejszego artykułu jest przedstawienie symulacji osuszania n-butanolu poprzez destylację heteroazeotropową z wykorzystaniem czterech różnych składników: toluenu, p-ksylenu, cykloheksanu i n-heksanu. Wybór tych substancji jest podyktowany dostępnością literaturowych danych eksperymentalnych VLLE [8-11] opracowanych przez ich autorów z myślą o osuszaniu n-butanolu. Dla trzech pierwszych układów dopasowano współczynniki równania NRTL, a w przypadku mieszaniny z n-heksanem wzięto je z pracy poprzedniej [20]. Dopasowanych parametrów użyto w miejsce oryginalnych parametrów znajdujących się w bazie danych ChemCAD. W celach porównawczych symulację z toluenem i p-ksylenem wykonano również przy użyciu tych oryginalnych parametrów. Ponieważ woda tworzy z n-butanolem heteroazeotrop, przeprowadzono także symulację bez wykorzystania składnika trzeciego.

\section{Model termodynamiczny}

Współczynniki aktywności ułamkowej $\gamma_{i}$ w fazie ciekłej obliczano za pomocą równania NRTL, które w swojej podstawowej formie ma trzy parametry dobieralne: $A_{i j}$, $A_{j i}$ oraz $\alpha_{i j}$. $A_{i j}$ wyraża różnicę między oddziaływaniami energetycznymi cząstek typu $i$ oraz $j$ względem oddziaływań cząstek typu $j$ oraz $j, A_{j i}$ wyraża różnicę między oddziaływaniami cząstek typu $j$ oraz $i$ względem oddziaływań cząstek typu $i$ oraz $i$, a $\alpha_{i j}$ jest parametrem ujmującym nieprzypadkowe ułożenie cząstek w roztworze. Nie potrafimy tych współczynników wyliczyć w sposób teoretyczny, dlatego parametry te dopasowuje się, wykorzystując dane eksperymentalne opisujące fizyczne równowagi fazowe typu VLLE, VLE i LLE. W pracy współczynniki równania NRTL obliczono poprzez minimalizację funkcji celu $F C$ ujętej równaniem (3).

$$
\ln \gamma_{i}=\frac{\sum_{j=1}^{N} \tau_{j i} G_{j i} x_{j}}{\sum_{l=1}^{N} G_{l i} x_{l}}+\sum_{j=1}^{N} \frac{x_{j} G_{i j}}{\sum_{l=1}^{N} G_{l j} x_{l}}\left(\tau_{i j}-\frac{\sum_{k=1}^{N} \tau_{k j} G_{k j} x_{k}}{\sum_{l=1}^{N} G_{l j} x_{l}}\right)
$$

$$
\begin{gathered}
\tau_{j i}=\frac{A_{j i}}{T} G_{j i}=\exp \left(-\alpha_{j i} \tau_{j i}\right) \\
F C=\sum_{i=1}^{N L L E} \sum_{j=1}^{N c} \sum_{k=1}^{2}\left(x_{\mathrm{exp}, k, j, i}-x_{o b l, k, j, i}\right)^{2}+ \\
+W 1 \sum_{i=1}^{N V L E} \sum_{j=1}^{N c}\left(y_{\mathrm{exp}, j, i}-y_{o b l, j, i}\right)^{2}+ \\
+W 2 \sum_{i=1}^{N V L E}\left(T_{\mathrm{exp}, i}-T_{o b l, i}\right)^{2}
\end{gathered}
$$

gdzie $x$ i $y$ to ułamki molowe w fazie ciekłej i gazowej, $T$ to temperatura $\mathrm{w} \mathrm{K}$, a $i, j, k$ oraz $l$ to indeksy poszczególnych składników.

Funkcja $F C$ używa $N L L E$ punktów doświadczalnych związanych z równowagą ciecz-ciecz. Można tu wykorzystać dane dotyczące VLLE oraz LLE danej trójskładnikowej mieszaniny. Pierwszy składnik minimalizowanej funkcji uwzględnia sumowanie po wszystkich składnikach $N c$ i obu fazach (wodnej 
i organicznej). Drugi człon funkcji celu wykorzystuje $N V L E$ punktów równowagi ciecz-para i także uwzględnia wszystkie składniki Nc. Dane te mogą dotyczyć VLLE i VLE danej trójskładnikowej mieszaniny oraz zawartych w niej układów dwuskładnikowych. Trzeci składnik minimalizowanej funkcji celu obejmuje różnice temperatur dla NVLE punktów doświadczalnych równowag ciecz-para. Wielkości $W 1$ i $W 2$ są parametrami wagi umożliwiającymi lepsze dopasowanie obliczanej wielkości. Chodzi tu o skład fazy gazowej lub obu faz ciekłych albo o temperaturę. Obliczone ułamki molowe i temperatury dla wszystkich faz pojawiających się w równaniu (3) opisują pełną równowagę VLLE. Dla mieszaniny trójskładnikowej minimalizowana funkcja celu oblicza 9 współczynników $\left(A_{12}, A_{21}, A_{13}, A_{31}, A_{23}, A_{32}, \alpha_{12}, \alpha_{13}\right.$ i $\alpha_{23}$ ). Szczegółowy opis algorytmu obliczania tych parametrów przedstawiono $\mathrm{w}$ pracy [20].

Tablica 1 wyszczególnia rozpatrywane w pracy mieszaniny, a tablica 2 przedstawia obliczone wartości parametrów modelu NRTL-VLL dla tych mieszanin. Wartości parametrów w przypadku mieszaniny woda-n-butanol-n-heksan są przedstawione $\mathrm{w}$ pracy [20]

Poniżej przedstawiono wartości reprezentujące kryterium dokładności korelacji i przewidywania równowag VLLE i VLE. $\Delta x_{i}, \Delta y_{i}$ to absolutne średnie odchylenie pomiędzy eksperymentalnymi i równowagowymi stężeniami składnika $i$ odpowiednio $\mathrm{w}$ fazach ciekłej i gazowej, a $\Delta T$ - abso-

Tablica 1. Zakres temperatur i ciśnień oraz liczba punktów eksperymentalnych dla danych VLLE

\begin{tabular}{|c|l|c|c|c|c|}
\hline $\mathrm{Nr}$ & \multicolumn{1}{|c|}{ Mieszanina } & $T[\mathrm{~K}]$ & $P[$ bar $]$ & lp. & Ref. \\
\hline 1 & woda-n-butanol-toluen & $356 \div 363$ & 1,013 & 23 & 11 \\
\hline 2 & woda-n-butanol-p-ksylen & $362 \div 366$ & 1,013 & 21 & 8 \\
\hline 3 & woda-n-butanol-cykloheksan & $342 \div 366$ & 1,013 & 20 & 9 \\
\hline
\end{tabular}

Tablica 2. Współczynniki równania NRTL dla mieszanin (1)-(3)

\begin{tabular}{|c|c|c|c|c|c|c|c|c|c|}
\hline $\mathrm{Nr}$ & $A_{12}$ & $A_{21}$ & $A_{13}$ & $A_{31}$ & $A_{23}$ & $A_{32}$ & $\alpha_{12}$ & $\alpha_{13}$ & $\alpha_{23}$ \\
\hline 1 & 1247,1 & 210,70 & 1693,7 & 1187,8 & 206,46 & 365,32 & 0,4094 & 0,3042 & 0,5866 \\
\hline 2 & 1239,1 & 204,31 & 1646,6 & 1314,7 & 265,66 & 352,23 & 0,4082 & 0,3242 & 0,8000 \\
\hline 3 & 1227,2 & 198,64 & 2140,5 & 1583,2 & 176,66 & 750,93 & 0,4055 & 0,2828 & 0,5473 \\
\hline
\end{tabular}

Tablica 3. Średnie odchylenia w przewidywaniu VLLE (wo - faza wodna, org - faza organiczna)

\begin{tabular}{|l|c|c|c|}
\cline { 2 - 4 } \multicolumn{1}{c|}{} & \multicolumn{3}{c|}{ Układ } \\
\cline { 2 - 4 } \multicolumn{1}{c|}{} & 1 & 2 & 3 \\
\hline$\Delta X w o$ & 0,0050 & 0,0050 & 0,0018 \\
\hline$\Delta X o r g$ & 0,0087 & 0,0084 & 0,0090 \\
\hline$\Delta Y$ & 0,0084 & 0,0079 & 0,0143 \\
\hline$\Delta T$ & 0,28 & 0,48 & 0,52 \\
\hline
\end{tabular}

lutne średnie odchylenie pomiędzy eksperymentalną i obliczoną równowagową temperaturą. Dodatkowo dla wygody zdefiniowano dwa średnie odchylenia $\Delta X \mathrm{i} \Delta Y$, ujęte równaniem (6). Pierwsze odnosi się do wszystkich składników danej fazy ciekłej, a drugie do wszystkich składników fazy gazowej.

$$
\begin{gathered}
\Delta x_{i}=\frac{1}{N L L E} \sum_{i=1}^{N L L E}\left|x_{\mathrm{exp}, i}-x_{o b l, i}\right|, \\
\Delta y_{i}=\frac{1}{N V L E} \sum_{i=1}^{N V L E}\left|y_{\mathrm{exp}, i}-y_{o b l, i}\right| \\
\Delta T=\frac{1}{N V L E} \sum_{i=1}^{N V L E}\left|T_{\mathrm{exp}, i}-T_{o b l, i}\right| \\
\Delta X=\frac{1}{N c} \sum_{i=1}^{N c} \Delta x_{i}, \\
\Delta Y=\frac{1}{N c} \sum_{i=1}^{N c} \Delta y_{i}
\end{gathered}
$$

Tablica 3 przedstawia wyniki obliczeń równowag VLLE dla mieszanin (1)-(3). Odchylenia $\Delta X$ są małe, nie przekraczają 1\% molowego i są niższe dla fazy wodnej. Odchylenia $\Delta Y$ tylko w jednym przypadku przekraczają $1 \%$ molowy. Wartości $\Delta T$ wahają się w granicach $0,28 \div 0,52$.

Tablica 4 prezentuje wyniki obliczeń VLE dla binarnych mieszanin składowych (woda-n-butanol i n-butanol-węglowodór). Dokładność przewidywania jest dość dobra pomimo tego, że temperatury dotyczące równowag VLE są w niektórych przypadkach istotnie różne od tych dla równowag VLLE. Należy również pamiętać, że układ woda-n-butanol wykazuje lukę mieszalności i z tej przyczyny opis jego VLE jest trudniejszy. 
Tablica 5. Porównanie eksperymentalnych i obliczonych stężeń (w ułamkach molowych) oraz temperatur dla trójskładnikowych i dwuskładnikowych azeotropów

\begin{tabular}{|c|c|c|c|c|c|c|c|c|c|}
\hline Lp. & Układ & $\begin{array}{l}\text { Ekspery- } \\
\text { mentalny }\end{array}$ & Obliczony & $\begin{array}{l}\text { Ekspery- } \\
\text { mentalny }\end{array}$ & Obliczony & $\begin{array}{l}\text { Ekspery- } \\
\text { mentalny }\end{array}$ & Obliczony & $\begin{array}{l}\text { Ekspery- } \\
\text { mentalny }\end{array}$ & Obliczony \\
\hline \multirow{5}{*}{1} & Woda & 0,530 & 0,537 & 0,750 & 0,756 & 0,561 & 0,560 & - & - \\
\hline & n-butanol & 0,075 & 0,091 & 0,250 & 0,244 & - & - & 0,327 & 0,339 \\
\hline & Toluen & 0,395 & 0,372 & - & - & 0,439 & 0,440 & 0,673 & 0,661 \\
\hline & $T[\mathrm{~K}]$ & 356,53 & 356,84 & 365,65 & 365,96 & 357,34 & 357,71 & 378,15 & 378,15 \\
\hline & Ref. & {$[11]$} & & [9] & & {$[11]$} & & [11] & \\
\hline \multirow{5}{*}{2} & Woda & 0,686 & 0,677 & 0,750 & 0,756 & 0,745 & 0,758 & - & - \\
\hline & n-butanol & 0,146 & 0,163 & 0,250 & 0,244 & - & - & 0,765 & 0,770 \\
\hline & p-ksylen & 0,168 & 0,160 & - & - & 0,255 & 0,242 & 0,235 & 0,230 \\
\hline & $T[\mathrm{~K}]$ & 362,40 & 362,97 & 365,65 & 366,00 & 365,15 & 365,57 & 389,15 & 389,38 \\
\hline & Ref. & [8] & & [9] & & [18] & & {$[6]$} & \\
\hline \multirow{5}{*}{3} & Woda & 0,294 & 0,292 & 0,750 & 0,744 & 0,300 & 0,300 & - & - \\
\hline & n-butanol & 0,044 & 0,045 & 0,250 & 0,256 & - & - & 0,090 & 0,089 \\
\hline & Cykloheksan & 0,662 & 0,663 & - & - & 0,700 & 0,700 & 0,910 & 0,911 \\
\hline & $T[\mathrm{~K}]$ & 341,83 & 342,10 & 365,65 & 365,30 & 342,65 & 342,50 & 352,75 & 352,58 \\
\hline & Ref. & [9] & & [9] & & [13] & & [9] & \\
\hline
\end{tabular}

Model NRTL-VLL został opracowany głównie z myślą o zastosowaniu go do modelowania destylacji heteroazeotropowej. Powinien on zatem jak najlepiej przewidywać stężenie, temperaturę i typ (homo- czy hetero-) tworzonego azeotropu. W tablicy 5 przedstawiono eksperymentalne i obliczone stężenia (w ułamkach molowych) oraz temperatury azeotropów rozpatrywanych mieszanin trójskładnikowych i ich binarnych podukładów. Niezbędne obliczenia zostały wykonane symulatorem ChemCAD. W większości przypadków dokładność przewidywania jest zadowalająca. Wszystkie trójskładnikowe mieszaniny z tablicy 5 tworzą heteroazeotropy i model NRTL-VLL prawidłowo przewiduje ten fakt.

\section{Symulacja osuszania n-butanolu}

Osuszanie n-butanolu może być przeprowadzone bez składnika trzeciego, ponieważ woda i n-butanol tworzą heteroazeotrop. Symulacja takiego procesu została porównana z wynikami obliczeń uzyskanymi przy użyciu: toluenu, p-ksylenu, cykloheksanu i n-heksanu. Parametry modelu NRTL-VLL dla układu woda-n-butanol-n-heksan przedstawiono w poprzedniej pracy autora [20]. Dla pozostałych układów parametry te są umieszczone w tablicy 2.

Rysunek 1 przedstawia schemat rozdziału mieszaniny woda-n-butanol (numery strumieni są umieszczone w kwadratach, a urządzeń w kółkach). Założono, że surowiec (strumień 1) zawiera $100 \mathrm{kmoli} / \mathrm{h}$ mieszaniny o składzie 95\% molowych wody i 5\% molowych n-butanolu. Strumień ten wstępuje do separatora faz ciekłych, gdzie doprowadza się również strumienie szczytowe z obu kolumn destylacyjnych. Są one mieszaninami azeotropowymi woda-n-butanol. Urządzenie symulujące separator może obliczać równowagę trójfazową ciecz-ciecz-para. W rozpatrywanych w pracy symulacjach występuje tylko równowaga ciecz-ciecz, a gazowy strumień opuszczający separator ma zawsze zerowy prze- pływ. Faza organiczna z separatora jest kierowana do kolumny 1 , a faza wodna do kolumny 2 . N-butanol i woda o wysokiej czystości (99,99\% molowego) są odbierane odpowiednio z dołu kolumn 1 i 2. Symulacja tej dwuskładnikowej mieszaniny była przeprowadzona przy użyciu parametrów modelu NRTL-VLL uzyskanych dla układu woda-n-butanol-toluen.

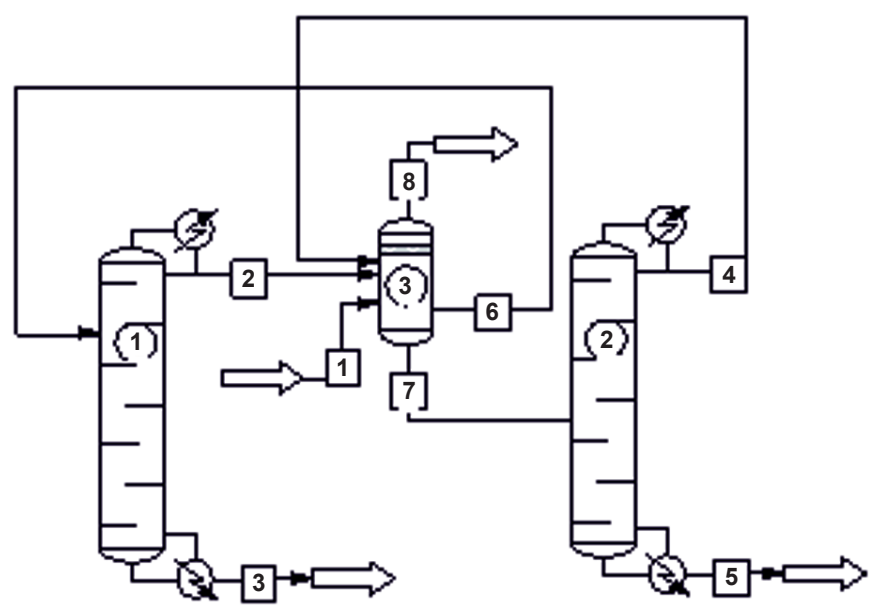

Rys. 1. Schemat rozdziału mieszaniny woda-n-butanol 
Tablica 6. Mieszanina woda (1) - n-butanol (2). Całkowity przepływ, stężenia (w ułamkach molowych) i temperatury strumieni 1, 2, 6, 7 i 4. Całkowita liczba półek i numery półek zasilających dla obu kolumn

\begin{tabular}{|l|c|c|c|c|c|c|c|c|}
\cline { 2 - 7 } \multicolumn{1}{c|}{} & \multicolumn{9}{c}{ Strumién } & \multicolumn{3}{c|}{ Kolumna } \\
\cline { 2 - 8 } \multicolumn{1}{c|}{} & 1 & 2 & 6 & 7 & 4 & & 1 & 2 \\
\hline $\mathrm{kmol} / \mathrm{h}$ & 100,00 & 10,99 & 15,98 & 99,49 & 4,49 & liczba półek & 9 & 8 \\
\hline$x_{1}$ & 0,9500 & 0,7561 & 0,5200 & 0,9889 & 0,7561 & nr półki strum. 6 & 2 & \\
\hline$x_{2}$ & 0,0500 & 0,2439 & 0,4800 & 0,0111 & 0,2439 & nr półki strum. 7 & & 3 \\
\hline$T[\mathrm{~K}]$ & 302,15 & 365,62 & 313,03 & 313,03 & 365,62 & & & \\
\hline
\end{tabular}

W przypadku wszystkich symulacji przeprowadzonych w pracy liczba półek w obu kolumnach została ustalona metodą prób tak, aby z dołu kolumna odprowadzała wodę lub n-butanol o założonej czystości. Numery półek zasilających w obu kolumnach też dobrano metodą prób w taki sposób, aby łączne ciepło dostarczone do wyparek obu kolumn i ewentualnych podgrzewaczy było jak najmniejsze.

W tablicy 6 przedstawiono całkowity przepływ, stężenie i temperaturę strumieni 1, 2, 6, 7 i 4 oraz całkowitą liczbę półek i numery półek zasilających dla obu kolumn. Azeotropy odprowadzane ze szczytu obu kolumn destylacyjnych (strumienie 2 i 4) mają temperaturę i stężenie prawie takie same jak odpowiadające im eksperymentalne wartości zawarte w tablicy 5 .

Wartości liczbowe eksperymentalnych równowagowych ułamków molowych dla mieszaniny woda-n-butanol i $T=313,15 \mathrm{~K}$ prezentuje tablica 2 pracy [11]. Wynoszą one: $x_{1, \text { org }}=0,516 ; x_{2, \text { org }}=0,484$ i $x_{1, \text { wo }}=0,981 ; x_{2, \text { wo }}=0,019$. Autorzy pracy [11] ocenili błąd względny zmierzonego ułamka molowego na poziomie $2 \%$. Ponieważ stężenia strumieni 6 i 7 z tablicy 6 są bardzo bliskie wartościom eksperymentalnym, można stwierdzić, że parametry modelu NRTL-VLL pracują bardzo dobrze dla rozważanej mieszaniny binarnej.

Tablica 7. Ilości ciepła odebranego i dostarczonego

\begin{tabular}{|c|c|c|c|}
\cline { 2 - 4 } \multicolumn{1}{c|}{} & Kolumna 1 & Kolumna 2 & Suma \\
\hline$Q^{-}[\mathrm{MJ} / \mathrm{h}]$ & $-511,73$ & $-208,78$ & $-720,51$ \\
\hline$Q+[\mathrm{MJ} / \mathrm{h}]$ & 662,93 & 681,86 & 1344,79 \\
\hline
\end{tabular}

Tablica 7 prezentuje bilans cieplny symulacji. Uwzględnia on osobno sumaryczne ciepło odebrane w kondensatorach obu kolumn destylacyjnych $\left(Q^{-}\right)$oraz sumaryczne ciepło dostarczone do wyparek tych kolumn $\left(Q^{+}\right)$.

Rysunek 2 przedstawia schemat osuszania n-butanolu z użyciem węglowodorów. Surowiec (strumień 1) trafia nie do kolumny destylacyjnej 1 , ale do separatora 3. Takie rozwiązanie jest energetycznie bardziej uprzywilejowane. Separator jest również zasilany przez szczytowy produkt z kolumny azeotropowej 2 , wykroplony uprzednio w chłodnicy 4 .

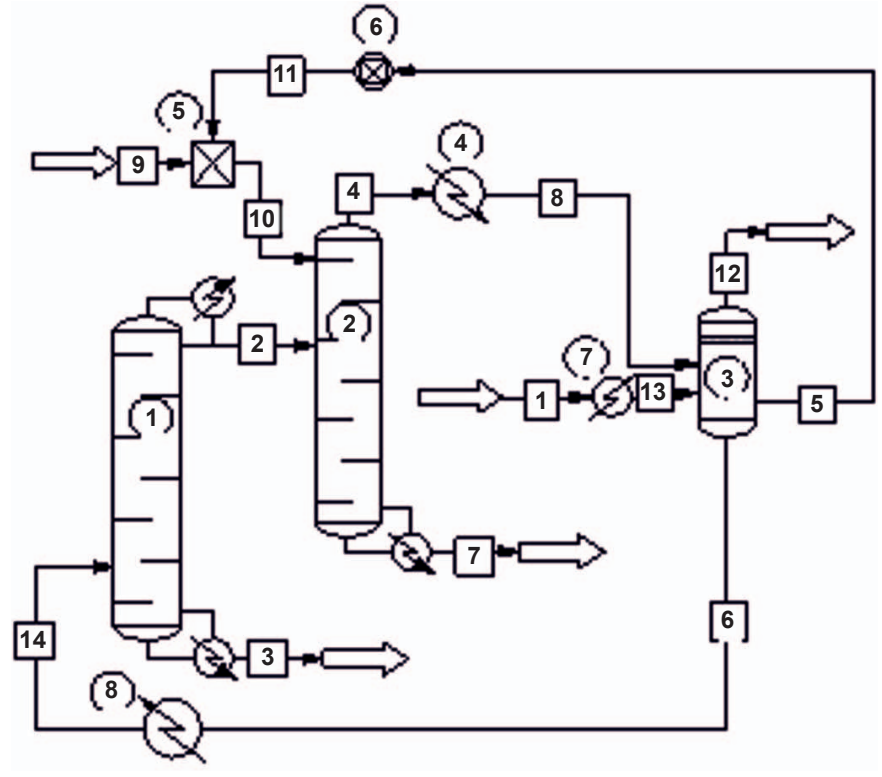

Rys. 2. Schemat osuszania n-butanolu przy użyciu składnika trzeciego

Surowiec ma taki sam przepływ i stężenie jak w poprzedniej symulacji, ale jest podgrzewany w wymienniku ciepła 7 do temperatury strumienia 8 . Faza organiczna z separatora zostaje skierowana na pierwszą półkę kolumny azeotropowej 2, która nie ma skraplacza. $Z$ dołu tej kolumny odpływa n-butanol o czystości 99,99\%, a górą strumień mający skład i temperaturę bliską azeotropowi trójskładnikowemu rozpatrywanej mieszaniny. Faza wodna z separatora jest podgrzewana i częściowo odparowywana w wymienniku 8 , tak aby strumień 14 miał udział fazy parowej równy 0,1 . Strumień z dołu kolumny 1 zawiera 99,99\% molowego wody, a produkt szczytowy przechodzi do kolumny 2 jako faza gazowa. Urządzenie 6 to kontroler, który zlicza straty węglowodoru w strumieniach 3 i 7. Są one następnie uzupełniane strumieniem 9. Dla mieszaniny z toluenem stosunek orosienia (reflux ratio) na szczycie kolumny 1 był równy 1,6 i 1,7 odpowiednio dla modelu NRTL-VLL i współczynników równania NRTL wziętych z bazy danych ChemCAD. W pozostałych symulacjach wartość ta była równa 0,1 .

W tablicy 8 przedstawiono całkowity przepływ, stężenie i temperaturę strumieni 4, 5, 6 i 2 oraz całkowitą liczbę 
Tablica 8. Całkowity przepływ, stężenia (w ułamkach molowych) i temperatury strumieni 4, 5, 6 i 2. Całkowita liczba półek i numery półek zasilających dla obu kolumn; $x_{1}, x_{2}$ i $x_{3}$ - ułamki molowe odpowiednio: wody, n-butanolu i węglowodoru

\begin{tabular}{|c|c|c|c|c|c|c|c|c|}
\hline \multirow{2}{*}{ Węglowodór } & & \multicolumn{4}{|c|}{ Strumień } & & \multicolumn{2}{|c|}{ Kolumna } \\
\hline & & 4 & 5 & 6 & 2 & & 1 & 2 \\
\hline \multirow{5}{*}{ Toluen } & $\mathrm{kmol} / \mathrm{h}$ & 13,36 & 11,59 & 101,77 & 6,75 & liczba półek & 10 & 15 \\
\hline & $x_{1}$ & 0,5424 & 0,2006 & 0,9819 & 0,7282 & nr półki strum. 14 & 4 & \\
\hline & $x_{2}$ & 0,1365 & 0,4535 & 0,0154 & 0,2306 & nr półki strum. 10 & & 1 \\
\hline & $x_{3}$ & 0,3211 & 0,3459 & 0,0027 & 0,0412 & nr półki strum. 2 & & 7 \\
\hline & $T[\mathrm{~K}]$ & 357,55 & 356,45 & 356,45 & 364,61 & & & \\
\hline \multirow{5}{*}{$\begin{array}{l}\text { Toluen } \\
\text { Wsp. rów. } \\
\text { NRTL z ChemCAD }\end{array}$} & $\mathrm{kmol} / \mathrm{h}$ & 10,13 & 10,39 & 99,73 & 4,72 & liczba półek & 10 & 15 \\
\hline & $x_{1}$ & 0,5209 & 0,1251 & 0,9924 & 0,8414 & nr półki strum. 14 & 4 & \\
\hline & $x_{2}$ & 0,1458 & 0,5506 & 0,0075 & 0,1576 & nr półki strum. 10 & & 1 \\
\hline & $x_{3}$ & 0,3333 & 0,3242 & 0,0001 & 0,0010 & nr półki strum. 2 & & 7 \\
\hline & $T[\mathrm{~K}]$ & 356,05 & 355,08 & 355,08 & 368,14 & & & \\
\hline \multirow{5}{*}{ p-ksylen } & $\mathrm{kmol} / \mathrm{h}$ & 29,09 & 17,23 & 111,86 & 16,85 & liczba półek & 11 & 14 \\
\hline & $x_{1}$ & 0,6792 & 0,3203 & 0,9766 & 0,8450 & nr półki strum. 14 & 3 & \\
\hline & $x_{2}$ & 0,2104 & 0,5131 & 0,0204 & 0,1349 & nr półki strum. 10 & & 1 \\
\hline & $x_{3}$ & 0,1103 & 0,1666 & 0,0030 & 0,0201 & nr półki strum. 2 & & 3 \\
\hline & $T[\mathrm{~K}]$ & 363,89 & 362,64 & 362,64 & 368,36 & & & \\
\hline \multirow{5}{*}{$\begin{array}{l}\text { p-ksylen } \\
\text { Wsp. rów. } \\
\text { NRTL z ChemCAD }\end{array}$} & $\mathrm{kmol} / \mathrm{h}$ & 22,18 & 14,97 & 107,21 & 12,20 & liczba półek & 11 & 14 \\
\hline & $x_{1}$ & 0,6749 & 0,2499 & 0,9909 & 0,9204 & nr półki strum. 14 & 3 & \\
\hline & $x_{2}$ & 0,2363 & 0,6194 & 0,0090 & 0,0785 & nr półki strum. 10 & & 1 \\
\hline & $x_{3}$ & 0,0888 & 0,1307 & 0,0001 & 0,0011 & nr półki strum. 2 & & 3 \\
\hline & $T[\mathrm{~K}]$ & 364,01 & 361,62 & 361,62 & 370,70 & & & \\
\hline \multirow{5}{*}{ Cykloheksan } & $\mathrm{kmol} / \mathrm{h}$ & 49,96 & 39,14 & 110,81 & 15,81 & liczba półek & 12 & 10 \\
\hline & $x_{1}$ & 0,3086 & 0,0227 & 0,9884 & 0,9191 & nr półki strum. 14 & 3 & \\
\hline & $x_{2}$ & 0,0675 & 0,1830 & 0,0109 & 0,0758 & nr półki strum. 10 & & 1 \\
\hline & $x_{3}$ & 0,6239 & 0,7943 & 0,0007 & 0,0051 & nr półki strum. 2 & & 2 \\
\hline & $T[\mathrm{~K}]$ & 343,14 & 341,66 & 341,66 & 370,55 & & & \\
\hline \multirow{5}{*}{$\begin{array}{l}\text { Cykloheksan } \\
\text { Inne rozwiązanie }\end{array}$} & $\mathrm{kmol} / \mathrm{h}$ & 35,07 & 22,44 & 112,62 & 17,62 & liczba półek & 12 & 10 \\
\hline & $x_{1}$ & 0,7536 & 0,5276 & 0,9730 & 0,8281 & nr półki strum. 14 & 3 & \\
\hline & $x_{2}$ & 0,2439 & 0,4689 & 0,0269 & 0,1714 & nr półki strum. 10 & & 1 \\
\hline & $x_{3}$ & 0,0025 & 0,0035 & 0,0001 & 0,0005 & nr półki strum. 2 & & 2 \\
\hline & $T[\mathrm{~K}]$ & 365,62 & 363,03 & 363,03 & 367,90 & & & \\
\hline \multirow{5}{*}{ n-heksan } & $\mathrm{kmol} / \mathrm{h}$ & 56,91 & 50,48 & 106,42 & 11,41 & liczba półek & 12 & 9 \\
\hline & $x_{1}$ & 0,1946 & 0,0052 & 0,9943 & 0,9475 & nr półki strum. 14 & 3 & \\
\hline & $x_{2}$ & 0,0444 & 0,1401 & 0,0043 & 0,0390 & nr półki strum. 10 & & 1 \\
\hline & $x_{3}$ & 0,7610 & 0,8548 & 0,0014 & 0,0135 & nr półki strum. 2 & & 3 \\
\hline & $T[\mathrm{~K}]$ & 334,60 & 333,89 & 333,89 & 371,30 & & & \\
\hline \multirow{5}{*}{$\begin{array}{l}\text { n-heksan } \\
\text { Inne rozwiązanie }\end{array}$} & $\mathrm{kmol} / \mathrm{h}$ & 29,24 & 22,40 & 106,84 & 11,83 & liczba półek & 12 & 9 \\
\hline & $x_{1}$ & 0,7640 & 0,5101 & 0,9913 & 0,9225 & nr półki strum. 14 & 3 & \\
\hline & $x_{2}$ & 0,2360 & 0,4899 & 0,0087 & 0,0775 & nr półki strum. 10 & & 1 \\
\hline & $x_{3}$ & 0,0000 & 0,0000 & 0,0000 & 0,0000 & nr półki strum. 2 & & 3 \\
\hline & $T[\mathrm{~K}]$ & 366,07 & 365,56 & 365,56 & 370,59 & & & \\
\hline
\end{tabular}

półek i numery półek zasilających dla obu kolumn. Stężenia i temperatury strumieni 4 uzyskane przy użyciu mode- lu NRTL-VLL są zbliżone do eksperymentalnych wielkości azeotropów trójskładnikowych. Dla mieszanin z toluenem 
i p-ksylenem tablica 8 przedstawia również rezultaty symulacji uzyskane dla współczynników równania NRTL wziętych $\mathrm{z}$ bazy danych ChemCAD. Stężenia strumieni 4 obliczone dla obu mieszanin są podobne do rezultatów uzyskanych z wykorzystaniem modelu NRTL-VLL, ale stężenia ciekłych faz organicznych (strumień 5) różnią się bardzo istotnie. Zostało to skomentowane w dalszej części pracy. W przypadku symulacji z użyciem cykloheksanu i n-heksanu całkowity przepływ strumieni 4 ma dużą wartość. Dla tych układów symulator ChemCAD znalazł też inne rozwiązania, mające mniejsze przepływy strumieni 4. Jednakże w tym przypadku węglowodór został prawie całkowicie wyeliminowany z układu.

Kluczowym problemem decydującym najbardziej o dokładności całej symulacji jest zgodność stężeń obu faz ciekłych powstałych w separatorze z eksperymentalnymi wartościami LLE. Zgodność ta została zobrazowana na rysunku 3. Zawiera on: punkty eksperymentalne równowagi ciecz-ciecz wzięte $z$ danych równowag ciecz-ciecz-para, linię opisującą te punkty poprzez model NRTL-VLL, cięciwę równowago- wą narysowaną kolorem brązowym na podstawie obliczonych w symulacji stężeń fazy organicznej i wodnej (odpowiednio strumienie 5 i 6 ) oraz trzy eksperymentalne cięciwy równowagowe narysowane kolorem zielonym. Aby nie zaciemniać rysunku zbyt dużą liczbą linii, wybrano tylko trzy cięciwy równowagowe najbliższe linii uzyskanej z symulacji. Dla mieszanin z toluenem i p-ksylenem narysowano kolorem czerwonym również cięciwy równowagowe obliczone z symulacji uzyskanych dla współczynników równania NRTL wziętych z bazy danych ChemCAD. Rysunek 3 pokazuje, że dla wszystkich czterech symulacji przeprowadzonych przy użyciu modelu NRTL-VLL linie łączące stężenia obu faz ciekłych utworzonych w separatorze wpisują się bardzo dobrze do trzech najbliższych eksperymentalnych cięciw równowagowych. Bardzo duże różnice pomiędzy obliczonymi rezultatami i eksperymentalnymi danymi LLE występują dla symulacji uzyskanych przy użyciu współczynników równania NRTL wziętych wprost z bazy danych ChemCAD. Te ostatnie nie nadają się zatem do modelowania destylacji heteroazeotropowej.
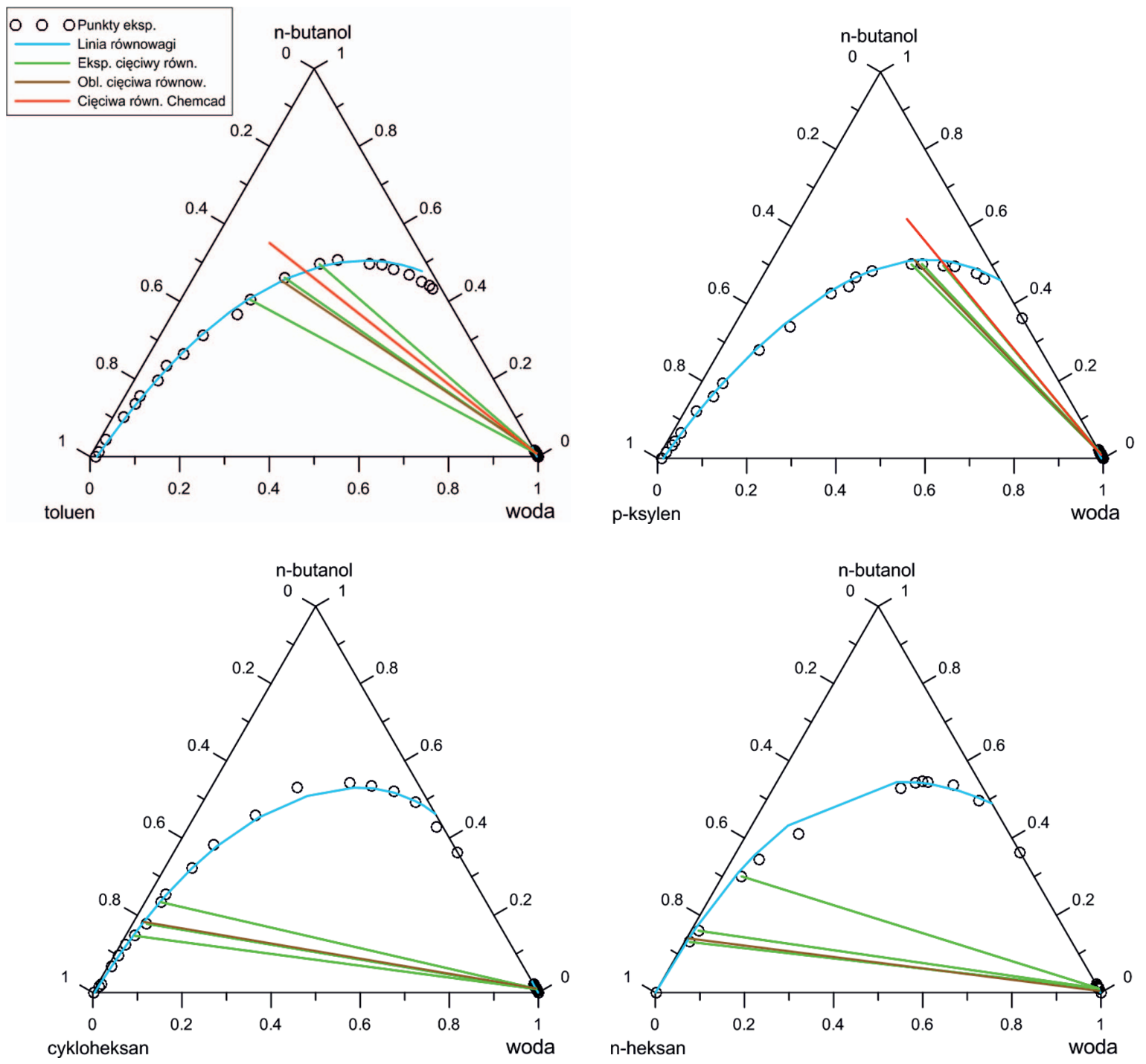

Rys. 3. Porównanie stężeń obu faz ciekłych powstałych w separatorze z eksperymentalnymi wartościami LLE 
Tablica 9. Wymagania energetyczne dla układów woda-n-butanol-węglowodór

\begin{tabular}{|c|c|c|c|c|c|c|c|}
\hline Węglowodór & & Kolumna 1 & Kolumna 2 & Wymiennik 4 & Wymiennik 7 & Wymiennik 8 & Suma \\
\hline \multirow{2}{*}{ Toluen } & $Q^{-}[\mathrm{MJ} / \mathrm{h}]$ & $-458,2$ & - & $-536,6$ & - & - & $-994,2$ \\
\hline & $Q^{+}[\mathrm{MJ} / \mathrm{h}]$ & 363,6 & 290,3 & - & 443,2 & 521,5 & 1618,6 \\
\hline \multirow{2}{*}{ P-ksylen } & $Q^{-}[\mathrm{MJ} / \mathrm{h}]$ & $-69,5$ & - & $-1224,5$ & - & - & $-1294,0$ \\
\hline & $Q^{+}[\mathrm{MJ} / \mathrm{h}]$ & 356,6 & 551,5 & - & 494,8 & 515,5 & 1918,4 \\
\hline \multirow{2}{*}{ Cykloheksan } & $Q^{-}[\mathrm{MJ} / \mathrm{h}]$ & $-64,9$ & - & $-1769,0$ & - & - & $-1833,9$ \\
\hline & $Q^{+}[\mathrm{MJ} / \mathrm{h}]$ & 294,8 & 1138,2 & - & 321,0 & 704,1 & 2458,1 \\
\hline \multirow{2}{*}{$\begin{array}{l}\text { Cykloheksan } \\
\text { Inne rozwiązanie }\end{array}$} & $Q^{-}[\mathrm{MJ} / \mathrm{h}]$ & $-72,8$ & - & $-1493,1$ & - & - & $-1565,9$ \\
\hline & $Q+[\mathrm{MJ} / \mathrm{h}]$ & 391,1 & 784,6 & - & 497,7 & 516,8 & 2187,2 \\
\hline \multirow{2}{*}{ N-heksan } & $Q^{-}[\mathrm{MJ} / \mathrm{h}]$ & $-46,7$ & - & $-1878,1$ & - & - & $-1924,8$ \\
\hline & $Q^{+}[\mathrm{MJ} / \mathrm{h}]$ & 107,1 & 1444,4 & - & 257,4 & 739,7 & 2548,6 \\
\hline \multirow{2}{*}{$\begin{array}{l}\text { N-heksan } \\
\text { Inne rozwiązanie }\end{array}$} & $Q^{-}[\mathrm{MJ} / \mathrm{h}]$ & $-48,5$ & - & $-1236,8$ & - & - & $-1285,3$ \\
\hline & $Q+[\mathrm{MJ} / \mathrm{h}]$ & 129,1 & 777,80 & - & 518,6 & 483,6 & 1909,1 \\
\hline
\end{tabular}

W tablicy 9 przedstawiono wymagania energetyczne dla poszczególnych symulacji. Podobnie jak w przypadku mieszaniny dwuskładnikowej uwzględniono oddzielnie ciepło odebrane w kondensatorze kolumny 1 i chłodnicy 4 oraz ciepło dostarczone do wyparek obu kolumn destylacyjnych i podgrzewaczy 7 i 8 . Tablica 9 pokazuje, że mniejsze wymagania energetyczne występują w symulacjach używających toluenu i p-ksylenu. Wyższe wymagania pojawiają się dla symulacji z cykloheksanem i n-heksanem z powodu większych przepływów strumieni obiegowych, przedstawionych w tablicy 8 (wymagania energetyczne są mniejsze, gdy węglowodór jest eliminowany z układu). Wartości ciepła odebranego i dostarczonego należy porównać z odpowiednimi wielkościami umieszczonymi w tablicy 7. Można zaobserwować, że rozdział mieszaniny woda-n-butanol na czyste substancje przy użyciu składnika trzeciego jest energetycznie mniej korzystny niż rozdział mieszaniny dwuskładnikowej. Dodatkowo w tym ostatnim przypadku rozdzielane substancje nie zawierają nawet małych ilości składnika trzeciego.
W przeprowadzonych symulacjach założono bardzo wysoki stopień czystości otrzymywanego alkoholu i wody (99,99\% molowego), gdyż dotychczas nie sprecyzowano maksymalnej dopuszczalnej zawartości wody w n-butanolu będącym składnikiem paliwa lub paliwem samodzielnym. W praktyce wymagana czystość byłaby zapewne mniejsza. Przeprowadzono więc również symulacje przy założeniu, że stężenia otrzymywanego n-butanolu i wody wynoszą $99,9 \%$ molowego. W przypadku rozdziału mieszaniny dwuskładnikowej woda-n-butanol wymagania energetyczne $Q-$ i $Q+$ były mniejsze niż uprzednio i wynosiły odpowiednio $96,4 \%$ i $97,5 \%$ tych z tablicy 7 . W przypadku symulacji wykonanych dla układów trójskładnikowych wielkości $Q-$ i $Q+$ też były mniejsze i sięgały odpowiednio przedziałów $88,4 \div 95,1 \%$ oraz $91,9 \div 96,7 \%$ wartości przedstawionych w tablicy 9 . Ponownie wyższe wymagania pojawiły się dla symulacji z cykloheksanem i n-heksanem z powodu większych przepływów strumieni obiegowych, ale najkorzystniejszy energetycznie był rozdział mieszaniny dwuskładnikowej.

\section{Podsumowanie}

Wyniki obliczeń równowagowych (tablice 3 i 4) pokazują, że równanie NRTL może opisywać z dobrą dokładnością jednym zestawem parametrów zarówno równowagi cieczciecz-para mieszanin trójskładnikowych (odchylenia $\Delta X$ nie przekraczają 1\% molowego, $\Delta Y$ mieszczą się w granicach $0,79 \div 1,43 \%$, a $\Delta T$ są w przedziale $0,28 \div 0,52 \mathrm{~K}$ ), jak i równowagi ciecz-para ich składowych układów dwuskładnikowych (odchylenia $\Delta y$ mieszczą się w przedziale $0,27 \div 1,39 \%$, a $\Delta T$ w zakresie $0,12 \div 0,62 \mathrm{~K}$ ). Współczynniki tego równania muszą być jednak starannie dopasowane równocześnie do trój- i dwufazowych danych równowagowych i obejmować cały zestaw 9 parametrów, jak w modelu NRTL-VLL.
Współczynniki dopasowane tylko do danych dwuskładnikowych nie są w stanie dokładnie opisać danych VLLE. Model NRTL-VLL oblicza także z dobrą dokładnością temperatury i stężenia trój- i dwuskładnikowych azeotropów (maksymalny błąd na temperaturze wynosi $0,57 \mathrm{~K}$, a na składzie $2,3 \%$ ) oraz prawidłowo przewiduje, że rozpatrywane mieszaniny trójskładnikowe tworzą heteroazeotropy.

W symulacjach przeprowadzonych dla układów trójskładnikowych strumienie odchodzące górą kolumny azeotropowej miały stężenia i temperatury bliskie eksperymentalnym wartościom odpowiednich azeotropów. W symulacji dotyczącej układu dwuskładnikowego woda-n-butanol stężenia i temperatury 
szczytowych produktów obu kolumn były prawie takie same jak wartości eksperymentalne azeotropu tej mieszaniny. Dokładność całej symulacji zależy w dużym stopniu od właściwego przewidywania stężeń obu faz ciekłych utworzonych w separatorze. Rysunek 3 pokazał, że stosując model NRTL-VLL, uzyskuje się linie łączące stężenia obu faz ciekłych pasujące bardzo dobrze do eksperymentalnych cięciw równowagowych. Również w przypadku symulacji dla binarnej mieszaniny woda-n-butanol obliczone ułamki molowe obu faz ciekłych były bardzo bliskie eksperymentalnym wartościom LLE. Całkowicie odmienny efekt uzyskuje się, stosując w symulacji oryginalne współczynniki równania NRTL z bazy danych ChemCAD. Obliczone tu cięciwy równowagowe odbiegają znacznie od eksperymentalnych danych LLE.

Dla układów trójskładnikowych mniejsze wymagania energetyczne występują w symulacjach używających toluenu i p-ksylenu. Jednak najbardziej korzystny energetycznie jest rozdział mieszaniny dwuskładnikowej woda-n-butanol.

Prosimy cytować jako: Nafta-Gaz 2016, nr 10, s. 863-871, DOI: 10.18668/NG.2016.10.12

Artykuł nadesłano do Redakcji 31.07.2016 r. Zatwierdzono do druku 6.10.2016 r.

\section{Literatura}

[1] Arifin S., Chien I. L.: Combined Preconcentrator/Recovery Column Design for Isopropyl Alcohol Dehydration Process. Ind. Eng. Chem. Res. 2007, vol. 46, no. 8, s. 2535-2543.

[2] Cairns B. P., Furzer I. A.: Multicomponent Three-phase Azeotropic Distillation. 3. Modern Thermodynamic Models and Multiple Solutions. Ind. Eng. Chem. Res. 1990, vol. 29, no. 7, s. $1383-1395$.

[3] Chang W. T., Huang C. T., Cheng S. H.: Design and Control of a Complete Azeotropic Distillation System Incorporating Stripping Columns for Isopropyl Alcohol Dehydration. Ind. Eng. Chem. Res. 2012, vol. 51, no. 7, s. 2997-3006.

[4] Chemctations Inc.: Chem CAD VI. Process Flowsheet Simulator. 6.4.0.5052 version, Huston, Texas, USA 2010.

[5] Font A., Asensi J. C., Ruiz F., Gomis V.: Application of isooctane to the dehydration of ethanol. Design of a column sequence to obtain absolute ethanol by heterogeneous azeotropic distillation. Ind. Eng. Chem. Res. 2003, vol. 42, no. 1, s. $140-144$.

[6] Galska-Krajewska A.: Vapour-Liquid Equilibria in Binary Systems: p-Xylene-Aliphatic Alcohols at $760 \mathrm{~mm} \mathrm{Hg}$. Rocz. Chem. 1967, vol. 41, s. 609-616.

[7] Gascón I., Martin S., Artigas H., López M. C., Lafuente C.: Isobaric vapour-liquid equilibrium of binary and ternary mixtures containing cyclohexane, $n$-hexane, 1,3-dioxolane and 1-butanol at 40.0 and $101.3 \mathrm{kPa}$. Chem. Eng. J. 2002, vol. 88, s. 1-9.

[8] Gomis V., Font A., Saquete M. D., García-Cano J.: Isothermal (liquid + liquid) equilibrium data at $T=313.15 \mathrm{~K}$ and isobaric (vapor + liquid + liquid) equilibrium data at $101.3 \mathrm{kPa}$ for the ternary system (water +1 -butanol $+p$-xylene). J. Chem. Therm. 2014, vol. 79, s. 242-247.

[9] Gomis V., Font A., Saquete M. D., García-Cano J.: LiquidLiquid, Vapor-Liquid, and Vapor-Liquid-Liquid Equilibrium Data for the Water-n-Butanol-Cyclohexane System at Atmospheric Pressure: Experimental Determination and Correlation. J. Chem. Eng. Data 2013, vol. 58, no. 12, s. 3320-3326.

[10] Gomis V., Font A., Saquete M. D., García-Cano J.: LLE, VLE and VLLE data for the water-n-butanol-n-hexane system at atmospheric pressure. Fluid Phase Equil. 2012, vol. 316, s. $135-140$.

[11] Gomis V., Font A., Saquete M. D., García-Cano J.: Phase equilibria of the water + 1-butanol + toluene ternary system at 101.3 kPa. Fluid Phase Equil. 2015, vol. 385, s. 29-36.

[12] Gomis V., Pedraza R., Saquete M. D., Font A., García-Cano J.:
Ethanol dehydration via azeotropic distillation with gasoline fractions as entrainers: A pilot-scale study of the manufacture of an ethanol-hydrocarbon fuel blend. Fuel 2015, vol. 139, s. $568-574$.

[13] Horsley L. H.: Azeotropic Data. Advances in Chemistry Series Number 35, American Chemical Society, Washington 1962.

[14] Mączyński A., Biliński A., Oracz P., Treszczanowicz T.: Verified vapor-liquid equilibrium data. Vol. 6. Binary systems of $C_{4+}$ hydrocarbons and alcohols. Warszawa, PWN, 1982.

[15] Mączyński A., Skrzecz A.: Verified vapor-liquid equilibrium data. Vol. 7. Binary two-liquid systems of water and organic compounds. Warszawa, PWN, 1983, s. 58, data 14.

[16] Pla-Franco J., Lladosa E., Loras S., Montón J. B.: Isobaric Vapor-Liquid-Liquid Equilibria for the Ternary Systems Ethanol + Water + Propyl Acetate and 1-Propanol + Water + Propyl acetate. J. Chem. Eng. Data 2014, vol. 59, no. 6, s. 2054-2064.

[17] Pla-Franco J., Lladosa E., Loras S., Montón J. B.: Thermodynamic Analysis and Process Simulation of Ethanol Dehydration via Heterogeneous Azeotropic Distillation. Ind. Eng. Chem. Res. 2014, vol. 53, no. 14, s. 6084-6093.

[18] Serafimov L. A.: Dampf-Flüssig-Gleichgewicht im System Wasser - Essigsäure - p-Xylol bei $760 \mathrm{~mm} \mathrm{Hg.} \mathrm{Zh.} \mathrm{Prikl.}$ Khim. 1973, vol. 46, s. 2464-2467.

[19] Wu Y. C., Chien I. L.: Design and Control of Heterogeneous Azeotropic Column System for the Separation of Pyridine and Water. Ind. Eng. Chem. Res. 2009, vol. 48, no. 23, s. 10564-10576.

[20] Wyczesany A.: Calculation of Vapor-Liquid-Liquid Equilibria at Atmospheric and High Pressures. Ind. Eng. Chem. Res. 2014, vol. 53, no. 6, s. 2509-2519.

[21] Wyczesany A.: Wykorzystanie symulatora ChemCAD do modelowania destylacji heteroazeotropowej mieszanin zawierajacych wode i etanol. Przemysł Chemiczny 2011, t. 90, nr 7, s. $1419-1424$.

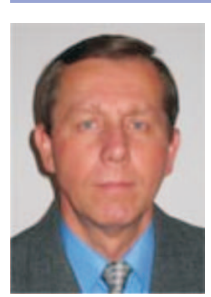

Dr inż. Andrzej WYCZESANY

Adiunkt na Wydziale Inżynierii i Technologii Chemicznej.

Politechnika Krakowska

ul. Warszawska 24

31-155 Kraków

E-mail:awyczes@chemia.pk.edu.pl 